УДК-78.03

\author{
Ялоза Антон Геннадійович, \\ викладач Дніпропетровської державної академії \\ імені М.Глинки, здобувач Одеської національної \\ музичної академії імені А.В.Нежданової \\ ORCID: 0000-0003-4740-0135 \\ antony.yaloza@gmail.com
}

\title{
МОЦАРТІАНСЬКІ СТИЛЬОВІ ВИМІРИ ВЕЛИКОЇ СОНАТИ ДЛЯ ГІТАРИ І ФОРТЕПІАНО Н.ПАГАНІНІ
}

\begin{abstract}
Метою роботи є теоретичне узагальнення через стильовий компаративний аналіз Великої сонати для гітари і фортепіано Н.Паганіні сутності бідермайерівських і романтичних торкань у засобах вираження, усвідомлюючи реалії розмежування італійського й німецького художнього світу у XIX ст. Методологічною основою дослідження виступає інтонаційний підхід школи Б.Асафьєва в Україні з виділенням вищевідміченого стильового компаративу і герменевтичного ракурсу його, як це маємо у працях О.Рощенко, О.Маркової, О.Муравської та ін. провідних музикознавців. Наукова новизна праці, по-перше, зумовлена оригінальністю теоретичної ідеї перетинів романтизму і бідермайєра у творчості Н.Паганіні, а, по-друге, вперше в музикознавчих здобутках України предметом дослідження стала Велика соната для гітари й фортепіано генія італійської музики XIX сторіччя. Висновки. Композиція Н.Паганіні демонструє показову для періоду бідермайєра як мистецтва Реставрації принципову опору на моцартіанське мислення, що відмежовується від пробетховенської солідарізації з позиціями Й.С.Баха. Опора на стильові ознаки музики Моцарта закономірні в межах італійського бідермайєра, налаштованого на вбирання салонних типологій вираження й національних рис останнього, показником яких стає сама речовість гітарного камерного звучання і вписаність гітарної гри у мистецький вжиток Італії, особливо що стосується італійського Півдня, з яким біографічно споріднений Паганіні.
\end{abstract}

Ключові слова: гітарне мистецтво, бідермайєр, романтизм, моцартіанство, бахіанство в музиці.

Ялоза Антон Григорьевич, преподаватель Днепропетровской государственной музыкальной академии имени М.Глинки, соискатель Одесской наииональной музыкальной академии имени А.В.Неждановой

Моцартианские стилевые измерения большой сонаты для гитары и фортепиано Н.Паганини

Целью данной работы выступает осознание через стилевой компаративный анализ Большой сонаты для гитары и фортепиано Н.Паганини сущности бидермаеровских и романтических касаний в средствах выражения, осознавая реалии размежевания итальянского и немецкого художественного мира в XIX ст. Методологической основой исследования выступает интонационный подход школы Б.Асафьєва в Украине с выделением вишеотмеченного стилевого компаратива и герменевтичного ракурса его, как это имеет место в работах А.Рощенко, Е.Марковой, О.Муравской и др. ведущих музыковедов. Научная новизна работы обусловлена - оригинальностью теоретической идеи пересечений романтизма и бидермайера в творчестве Н.Паганини, а, во-вторых, впервые в музыковедческих достижениях Украины предметом исследования предстала Большая соната для гитары и фортепиано гения итальянской музыки XIX век. Выводы. Композиция Н.Паганини демонстрирует показательную для периода бидермайера как искусства Реставрации принципиальную опору на моцартианское мышление, которое отмежевывается от пробетховенской солидаризации с позициями И.С.Баха. Опора на стилевые признаки музыки Моцарта закономерны в пределах итальянского бидермайера, настроенного на вбирание салонных типологий выражения и национальных черт последних, показателем которых становится сама вещественность гитарного камерного звучания и вписанность гитарной игры в художественный быт Италии, особенно что касается итальянского Юга, с которым биографически породнен Паганини.

Ключевые слова: гитарное искусство, бидермайер, романтизм, моцартианство, бахианство в музыке.

Yaloza Antony, lecturer, Dnipro State Music Academy named after M. GLinka, competitor Odessa National Music Academy named after A.V. Nezhdanova

Mozart style measurements in the large sonata for guitar and piano of N.Paganini

The purpose of the article emerges the realization through style comparative analysis of the Big sonata for guitar and pianoforte N.Paganini essence of the Biedermeier and romantic osculations in the facility of the expression, realizing creature to demarcations in Italian and german artistic world of XIX cent. Methodology of the study emerges the intonation approach of the school B.Asafitv in Ukraine with separation of above style comparative and hermeneutic foreshortening him as in the case in work of A.Roschenko, E.Markova, O.Muravskaja, and others leading musicologist. Scientific novelty of the work is conditioned - originality to theoretical idea of the crossing the romanticism and Biedermeier in the creative activity of N.Paganini, but, secondly, for the first time in musicology achievements of Ukraine by subject of the study appeared the Big sonata for guitar and piano of genius to Italian music of XIX age. Conclusions. The composition N.Paganini demonstrates significant for the period of Biedermeier as art to Restorations

С Ялоза А. Г., 2019 
principle full tilt on thinking in Mozart style, which is marked from solidarity with position I.S.Bach in Beethoven style. The handhold on style signs musics of Mozart natural within Italian Biedermeier, adjusted on вбирание salon typology of the expression and national devil of the lasts, which factor becomes corporeality guitar chamber itself sounding and вписанность guitar game in artistic mode of life to Italies, particularly as to Italian South, with which biographic is united, Paganini.

Key words: guitar art, Biedermeier, romanticism, the type of Mozart style, the type of Bach style in music.

Актуальність теми дослідження зумовлена неосимволістськими-необідермайєрівськими здобутками поставангарду, полістилістичний заряд якого виповнився розмаїттям класичних і акласичних стильових показників, у тому числі це реанімація з 1970-х символізму («неосимволізм» за О.Марковою [7, c. 99-134]) й історично його підготовлюваного бідермайєра (див.[13]). 3 них останній - бідермайєр - став тлом високого піднесення гітарного мистецтва в першій половині ХІХ ст. й відповідних творчих діянь Н.Паганіні, гітариста-виконавця і композитора. Цей бік мистецької спадщини в ракурсі продуктивності гітарного внеску Паганіні певною мірою дістала відображення в музикознавчих виданнях, зокрема в дисертації Н.Неделєвої-Ілієвої [9]. Але уточнення стилістичних подань Паганіні в його відтворенні епохальних переваг не акцентувалися в музикознавчих розвідках. Безсумнівною є послідовно-романтична позиція геніального скрипаля із притаманним йому романтичним бахіанством, але поєднаного зі стильовими виборами, досить відмінними від концепції Віденської школи i, особливо, від широко підтримуваного німецькими романтиками бетховеніанства.

Метою даної роботи виступає усвідомлення через стильовий компаративний аналіз Великої сонати для гітари й фортепіано Н.Паганіні сутності бідермайєрівських і романтичних торкань у засобах вираження з урахуванням реалій розмежування італійського й німецького художнього світу у ХІХ ст. Методологічною основою дослідження виступає інтонаційний підхід школи Б.Асаф'єва [2] в Україні 3 виділенням вищезазначеного стильового компаративу й герменевтичного ракурсу його, як це маємо в працях О.Рощенко, О.Маркової [7], О.Муравської [8] та ін. видатних музикознавців. Наукова новизна праці зумовлена, по-перше, оригінальністю теоретичної ідеї перетинів романтизму й бідермайєру у творчості Н.Паганіні, а, по-друге, уперше у музикознавчих здобутках України висвітлена вказана у назві статті Велика соната для гітари й фортепіано генія італійської музики XIX сторіччя.

Велика соната Н.Паганіні для гітари й фортепіано за типом вираження становить повну аналогію до скрипкової сонати чи іншого подібного ансамблю інструменталіста-соліста (струнника, духовика) 3 фортепіанною участю, але 3 тією суттєвою відмінністю, що за традицією старовинної сонати клавірна партія складає дещо базове, а в Паганіні соліст явно превалює у фактурному поданні жанру. Нагадуємо, що термін «соната» після 1750-х років збережений був тільки для представництва сонатного жанру в клавірі - фортепіано, а також для дуетів з опорним положенням останнього, оскільки інші ансамблеві сполучення стали називатися за кількістю учасників: тріо, квартет, квінтет і т.под. Такий підхід до жанрової позначеності знаменував чітко проведену Віденською школою секуляризацію-театралізацію музики, оскільки виток сонати - духовний, вихідною і церковно-освяченою формою стала тріо-соната 3 притаманним їй із сакральних міркувань тріо-принципом (див.у О.Спишина [6] і Т.Полянської [10]).

Відомо, що Н.Паганіні певною мірою кокетував своєю романтичною «демонічністю», відпускаючи не за модою, не за лицем зачіску «чорних кучерів до плечей» і дійсно дратуючи церковні кола Італії та інших країн своєю антирелігійною бравадою. I хоч це було не небезпечно, і це ми знаємо з біографії славетного музиканта, але, після революційних подій у Франції, після знищення з ініціативи Наполеона консерваторій Італії, які були при церквах [3, с. 82], - ті антирелігійні жести Паганіні не підлягали негайному офіційному нищенню.

Порівняння структури Великої сонати Паганіні із фортепіанними, скрипковими сонатами Віденців, які уособлювали, перш за все у персоні Л.Бетховена, новий театралізований-симфонізований художньосамодостатній інструменталізм і відверто тяжіли до «укрупнення» звучання композицій і тому минали камерний принцип гітари, - показує відмежування Паганіні від вказаної лінії Віденської школи (як це помітно і в текстах скрипкових Концертів майстра). Сдиний прийнятний з Віденців для Паганіні В.Моцарт, з його підкресленою опорою на італійські витоки й французькі позиції рококо. Італія в епоху Паганіні солідаризувалася з ідеями Рісорджименто, які мали виражену антинімецьку-антиавстрійську спрямованість. А значимість італійського сонатного принципу звучала в загальноєвропейському просторі почесно через діяльність М.Клементі, що був главою Лондонської клавірної школи, а його геніальним вихованцем став Дж.Фільд, виразник фортепіанного «перлинного» стилю 3 явним торканням заповітів клавесинного рококо.

Позиція Паганіні по-романтичному була послідовно суб'єктизованою й одночасно не могла не корегуватися 3 ідеями часу, як це видно із найбільш загальних обрисів його творчої біографії. Суб’єктивованим компонентом його діяльнісного вираження була його гітарна пристрасть. Гітара, 3 
одного боку, демонструвала національну специфіку італійського Півдня, що межував 3 місцем буття класичної гітари Європи, й одночасно втілювала показову для Півдня ( через етнічних греків, що заселяють цю територію й дотепер) пряму спадкоємність від грецької Античності і ії дітища - кіфаригітари. А італійський Південь уособлював початки Рісорджименто через карбонарієв, аристократичних повстанців, які дали згодом матеріал для оперних сюжетів про «шляхетних розбійників» на зразок Маркіза з «Фра-Дьяволо» Ф.Обера.

Таким чином, гітарна перевага Паганіні підкріплювала національний імідж великого музиканта, причому в актуальному ідейно-змістовному його прочитанні. Одночасно, як було вже зазначено, «гітарний бум» у першій половині XIX ст. був викликаний, зокрема, активною позицією народу Іспанії в антинаполеонівській війні й одночасно особливою увагою мистецьких кіл до камерності, у руслі якої склалася естетика-поетика бідермайєру й творчість класиків гітарного художньо-самодостатнього мистецтва цього роду (Й.Мерц, М.Макаров, ін.).

Одночасно Паганіні своєю персоною уособлював романтичний тип творчості i, більше того, поведінковий «чайльд-гарольдівський» комплекс протистояння суспільству, включаючи національних представників того офіційного «натовпу», від якого жорстко відділяли себе діячі романтизму. В цьому плані символіка «скрипки Паганіні» демонструвала своїм «бахіанством» всередині національної гідності славетної італійської скрипкової школи, яка поставляла майстрів-інструменталістів усьому світу протягом попередніх XVII-XVIII ст., принципову зверненість до глибин німецького духу, до поліфонізму Й.С.Баха, з яким ніяк не змішувалися для Паганінін ознаки Віденців пори його діяльності.

Та італійська скрипкова школа припинила своє існування зі смертю Паганіні, можливо, саме через безперспективність руху по тому шляху поліфонізації-«бахіанізації» італійської скрипки, суто мелодичного інструмента, який для неї, як «скрипки-оркестру», намітив геній Паганіні.

Той екскурс у «скрипку-оркестр» великого майстра зроблений заради усвідомлення самої ідеї Великої сонати для гітари й фортепіано, яка претендує самою назвою своєю на вихід за межі камерності, які $є$ природними для гітарного мистецтва бідермайєрівської пори. Але романтичне тяжіння до матеріального «збагачення» гідної ідеї (до речі, унаслідуваного від класицистського «матерієцентризму» і повністю протилежного бідермайєру, де ікону «шанували не за те, що вона велика» [8, с. 147]), явно стимулювало композиційне рішення Паганіні як автора вказаної Сонати.

Нагадуємо, що сонатна продукція була історично зумовлена буттям тріо-сонати, де басову партію представляв регістрово відповідний інструмент, у клавірному виконанні «цифрований», тобто фактурно «уважнений». Але від часів Дж.Тартіні і Й.С.Баха ствердилася соната-соло для скрипки і з нею конкуруючих інструментів, даючи тим привід для витіснення на другий план сприйняття клавірну складову, коли вона з'являється в сонаті. Для сонат Віденців такий фактурний поворот був немислимим, тоді як Паганіні максимально «полегшує» участь фортепіано в дуеті. I якщо у перших двох частинах Сонати фортепіано має певну фактурну самостійність щодо гітари, то у фінальних Варіаціях гітара заполоняє всі фактурні «поверхи», залишаючи фортепіано суто акомпонувальну функцію.

Зі сказаного випливає послідовна жанрово-стилістична новаційність взятої в аналіз композиції, що відповідає творчій егоцентричності романтичного світовідчуття, але вловлюється ця романтична новаційність зовсім не за критеріями Віденської школи і ії німецької ж пролонгації в романтизм, які до останніх десятиріч у музикознавстві були єдиними у своєму роді показниками «новаційності» чи «консерватизму-академізму» в музичній сфері. Але «зняття табу» з обговорення самостійності шляху в романтизм для Італії (див.у А.Хохловкіної [12], у Д.Андросової [1] та ін.) дозволяє і в цьому разі захищати національну неповторність вирішення гітарної композиції, яка впевнено посіла гідне місце в репертуарі сучасних виконавців.

Сам принцип Великої сонати, з підкресленими віртуозними ознаками звучання гітарної партії, вказує на генетичну спорідненість цього жанру з концертом (див.у В.Бобровського про єдність сонатиконцерту-симфонії в генезі європейського інструменталізму [11, с. 193-194], а саме, з облігатним концертом-бароко, в якому ансамблево-оркестральна складова явно виступала як супровід соліста. Романтики відверто черпали з бароко, протиставляючи ті засоби та змісти класицистській послідовній героїчності, - і Паганіні не був тут винятком.

Три частини Сонати Паганіні демонструють послідовність, відпрацьовану в клавірних Сонатах Дж.Саммартіні і Дж.Мартіні. Базовою структурою є двочастинна послідовність швидко-повільніше («обернення» сюїтної першосонатної двоїстості повільно-швидше), до якої могла приєднуватися третя частина, зокрема, у вигляді малого циклу варіацій. У цьому разі (а це є спільним і з сонатними конструкціями В.Моцарта, який не приховував своєї спорідненості з італійською традицією) перші дві частини становлять подобу у побудові, оскільки тут домінує сонатна структура 3 наочними рисами старосонатності. 
Вказаний моцартівський нахил у структурі (до речі, улюблена Моцартом сфера А/а як вмістилище Небесного за піфагорійською шкалою [5, с. 239]) має ще одне підтвердження - у зв'язку з елементами концертної налаштованості концепції циклу. Початок Сонати, де намічена послідовність розгорнутої експозиції сонатного Allegro, після «майже по-віденськи» подаваної концертної урочистої звучності початкової теми (головна партія у сонатних відносинах, на ритмі славильності канта-шансона половинна і дві чверті) проходять дві теми (на ц.1 і на 4-му т.після ц.2).

Вони обидві явно виконують функцію двох зв'язуючих, з яких друга (4-й т.після ц.2) виділена унікальними для всієї сонати фактурною i, собливо, тональною, ознаками: псалмодуюча фігура у мелодії і зіставленням, після модуляції в E- dur у першій зв'язуючій (на ц.1) поданий C-dur. Але суттєвим видається те, що при викладенні цієї теми у гітари надана можливість повністю «замінити» гомофонногармонічну фактуру фортепіано, оскільки тема являє собою подання мелодичної лінії на фоні гітарою ж виконуваних фігурацій.

Згодом на ц. 3 показана побічна партія в Е- dur, ритмічна фігура якої похідна від другої зв’язуючої (половинна нота і чотири восьмих), але виділена авторською ремаркою «dolce». Із сказаного випливає особлива виразна значущість зв'язуючої в експозиції і в структурі I частини у цілому. А це - вже помоцартівськи: подібні теми в сонатних побудовах виділені за логікою ліризму композиційної схеми від вершини-витоку (див.значущість зв'язуючих партій у I Allegro Сонат Моцарта KV 457, 545, 570), а у фортепіанних Концертах Моцарт ввів спеціальні теми на рівні вступу солістів на зв'язуючій.

Далі (від ц.4) показані розвивавальні проведення на першій темі (головній партіі), причому, пасажна насиченість гітарної партії стає самодостатньою. Після вказаного розвивального фрагмента вступає реприза побічної, складаючи побічно-заключний комплекс експозиції. I на рівні ствердження спочатку зв'язуючої, а потім побічної партія гітари все більш фактурно розгортається, «покриваючи» ініціативу фортепіано.

Новий етап викладення - розробка (від ц.6), яка відкривається октавним унісоном у гітари на ритмі головної партії, але в протилежно спрямованій нисхідній послідовності (catabasis - знак Спокути). Далі велика роль призначається зв'язуючій, на якій побудовані тональні терцієві зсуви fis-D-h-G-C-a (від ц.7 до цц. 8 і 9), головне, представлений каденцієвий розворот партії соліста, який досягає апогею на рівні ц.9, де діалог пасажних декламаційних реплік і грізних акордів (останні - підтримувані фортепіано) знаменує високий драматичний, театрально-поданий підйом музичної дії.

Реприза (ц.10) підкреслена «сяянням» A-dur у поданні побічної, даної розгорнуто з контрастами пасажного розвитку і внутрішньою репризою, що дає єдність побічної-заключної. Така концепція репризи Allegro Сонати Паганіні споріднює дану авторську ідею з сонатним Allegro у Другій сонаті Ф.Шопена, які могли впливати одна на одну, оскільки спеціальна зверненість Шопена до італійської музики $\epsilon$ відомою, а «польотний» тип гри Шопена на «легких» фортепіано зближував його не 3 бетховенською лінією, а саме з моцартіанством та італійською профільдієвською клавірністю.

Друга частина Сонати - жанрово виділена: Романс, етимологічно - «римська пісня», тобто духовного кореня наспів. Героічно-епічні і любовно-страджальні виходи іспанського романсу були вельми відомими в Свропі, Паганіні ж позначкою Amorosamente («любовно») вказує на «полегшений» комплекс, явно спочатку ніби контрастуючий із драматичними заявленнями I частини. Більше того, моцартіанство Паганіні тут отримує документальне підгрунтя: тема Романсу у ритмі сициліани (жанру, що має духовні корені) складає нібито омінорений парафраз на тему варіацій I частини клавірної Сонати A-dur KV 331 Моцарта. А фінальна частина гітарної Сонати Паганіні, тема 3 варіаціями в A-dur, відтворює структуру-ідею вказаної I частини моцартівської Сонати.

Як уже зазначалося вище, Романс написаний у сонатній формі, причому, з рисами сполучення старовинної і класичної сонатності, як це мало місце і в I частиині твору (і у формотиворенні Ф.Шопена!). Перша тема, явно споріднена з моцартівським мелодійним стимулом, показує образ в a-moll - у варіанті «солодкого» мінору, притаманного духовній гимнотворчій традиції Італії, - i до якої був долучений Моцарт, який пишався своїм католицьким «містицизмом» [3, с.89].

Друга тема (на ц. 2), показана в C-dur (побічна партія у сонатних відносинах), демонструє розвиток, в якому маємо зіставлення фактурних утворень гітари й фортепіано, а перед ц. 3 музика відзначена пасажними елементами гри соліста, що наближає викладення до концертної каденції. На ц.3 маємо щось на зразок динамічної репризи, оскільки показ першої теми в мотивних зіставленнях проходить, тим не менш, у сфері a-moll. Але динамізованість викладення очевидна, більш того, очевидним є розробковий характер звучання, знов фактура наближається до концертного віртуозного соло в стилі каденції.

На ц.4 отримуємо репризу як таку, в основному a-moll і в експозиційному типові викладення, а за тим - 2-а тема, тільки ладово переосмислена, звучить, як і перша тема, в a-moll (як це робив і Моцарт у клавірних Сонатах KV 310 і 457, $з$ яких перша з названих також в a-moll, а друга в c-moll). Зі сказаного 
виходить, що II частина Сонати Паганіні подає явне фактурне наростання віртуозного наповнення, підхоплюючи тим самим драматичні заявлення розробкового розділу першого Allegro.

Фінальні Варації (варіацій 6, як і в Темі 3 варіаціями у Сонаті Моцарта A-dur KV 331) демонструють певну «дематеріалізацію» фактурного виявлення соліста, оскільки фортепіанна партія мінімалізована й дає змогу солісту-віртуозу показати повноту фактурного розгортання можливостей гітари. Ця симфонізація гітари, яка $є$ природною для еволюції всіх академічних інструментів, повторює у Паганіні шлях його «скрипки-оркестру», створюючи ефектний, але певною мірою утопічний «прорив», оскільки ця оркестральність від початку обмежена камерною природою класичної гітари.

Але знайдений ефект гітарного «романтичного балету», в якому, подібно до романтичних па-де-де, вміння партнера $є$ умовою «шаріння» балерини у «підтримках», фортепіанна партія скупо, але необхідновиразно підкреслює понадпишні пасажності гітариста, -- все це становить творче відкриття генія Паганіні. I ще більше вражає його знахідка, що він, продемонструвавши багаті можливості гармонічних модулюючих засобів у I, значною мірою у II частинах, в III зосереджується на чистому A-dur, а в акордово-гармонічному викладені дано майже повністю на послідовностях $\mathrm{T}$ i $\mathrm{D}$, обминаючи показ субдомінантової акордики. Тим самим весь тягар ствердження тематизму фіналу концентрується на фактурних засобах, наслідуючи тим мислення А.Вівальді та інших видатних інструменталістів Італіїбароко.

Не дивно, що ці знахідки Паганіні, оцінені в контексті фактурного тематизму і сонористичних відкрить другої половини XX ст., не викликав ентузіазму музикознавців-сучасників і XIX ст. вцілому: цінилися «розвивальні» можливості гармонічного мислення німецької школи, італійський шлях інтенсифікації статики надовго опинився під фахівським табу. Паганіні, як бачимо з викладеного, цілком усвідомлював відмінність свого шляху в концепції форми - навіть щодо надзвичайно ним шанованого В.Моцарта: варіації на тему у I частині Сонати A-dur KV 331 мають виражене тяжіння до сонатно-сюїтної динаміки, завершальна варіація явно демонструє синтез засобів розвитку попередніх варіацій.

Паганіні підходить до форми Варіацій з інших позицій: він 3 насолодою «занурюється» у світлоносний простір ладу A-dur, підкреслює тонічно-гармонічну врівноваженість зміни тонікидомінанти в гармонії, а нашарування «неможливих» віртуозних гіпербол партії гітари подає як спосіб інтенсифікування статики Краси у сприйнятті, яка самодостатня й не потребує «розвитку», але тільки все більшого «проникнення» в їі грані. Так вимальовується радикальна новаційність мислення Паганініромантика, але відповідна оцінка якої потребує прийняття не-динамічної концепції образа-форми. Відкриття мінімалізму у XX ст. й усвідомлення його значущості тільки у кінці минулого століття дозволяє сьогодні віддати належне генію Італії першої половини XIX ст.

I все ж романтичний принцип мислення був базисним для Паганіні: романтична антиномічність продиктувала йому зіставлення мислительних протилежностей динаміки і статики I-II і III частин Сонати. I це дійсно Велика соната, що мала могутній енергетичний виражальний запас, багатство якого відкрила епоха поставангарду, де прогресизм-динамізм становить одну з можливих граней поведінковомислительних операцій, тоді як очевидною цінністю приймаємо й дещо протилежне, а саме: самодостатню значущість традиційно-статичного початку. І ця двоїстість цінностей в Сонаті Паганіні, яка на сьогодні однозначно віддзеркалює надбання мислення й символіки доби спадковості поставангарду, в якій художній смак на рівних переймається як здобутками прогресистських відкрить Нового часу, так $\mathrm{i}$ консерватизму традицій, становили й становлять гідність культурної ходи й наслідування в ній досягнень попередніх поколінь.

Висновки. Композиція Н.Паганіні демонструє показову для періоду бідермайєру, як мистецтва Реставрації, принципову опору на моцартіанське мислення, що відмежовується від пробетховенської солідарізації з позиціями Й.С.Баха. Опори на стильові ознаки музики Моцарта закономірні в межах італійського бідермайєру, налаштованого на вбирання салонних типологій вираження і національних рис останнього, показником яких стає сама речовість гітарного камерного звучання і вписаність гітарної гри у мистецький вжиток Італії, особливо що стосується італійського Півдня, з яким біографічно споріднений Паганіні.

\section{Лimepamypa}

1. Андросова Д.В. Символизм и поликлавирность в фортепианном исполнительстве XX в. Монография. Одесса: Астропринт, 2014. 400 с.

2. Асафьев Б. Музыкальная форма как процесс. Москва - Ленинград, Музыка, 1971, 379 с.

3. Барбье П. История кастратов. С.-Петербург: Издат. Ивана Лимбаха, 2006. 303 с. 
4. Бальтазар Г.фон, Барт К., Кюнг Г. Богословие и музыка. Три речи о Моцарте. Москва, Библейско-Богословский институт св.апостола Андрея. $149 \mathrm{c.}$

5. Гудман Ф. Магические символы. Москва, 1995. 289 с. $148 \mathrm{c}$.

6. Епишин А.В. Магия музыки барокко: итальянская трио-соната. Санкт-Петербург, Композитор., 2006.

7. Маркова Маркова Е. Проблемы музыкальной культурологии. Одесса, Астропринт, 2012. 164 с. неоевроп. С. 99-134

8. Муравська О. Нариси з історії зарубіжної музичної культури. Вип.1. Одеса: Друкарський дім, 2010. 214 c. $145-176$

9. Недева-Илиева Н.Я. Концернаят репертоар по китарнато и музикалнато развитие на ученика. Автореферат на дисертация... на нучната степен «доктор» 05.08 .02 - Музикознание и музикално изкуство. София 2016. $60 \mathrm{c}$.

10. Полянская Т.П. Трио-соната как жанровый феномен VII-XVIII ст. канд.дисс., специальность 17.00.03 - музыкальное искусство, ОНМА им. А. В. Неждановой, Одесса, 2016. 163 с.

11. Соната [В. Бобровский Музыкальная энииклопедия в 6-ти томах. Гл.ред. Ю.Келдыи. Т. 5 СИМОНХЕЙЛЕР. Москва: Сов. энциклопедия, 1981. С. $193-200$.

12. Хохловкина А. Западноевропейская опера. Конец XVIII - первая половина XIX века. Очерки. Москва, Гос.муз.издат., 1962. 368 с.

13. Heusler H. Das Biedermeier in der Musik. Die Musikforschung. XII Jahrgang. Basel-Kassel, Barenreiter Verlag, 1959, S.422-431.

\section{References}

1. Androsova D.V. (2014). Symbolism and polyklavier type in piano performance art XX century. Monograph. Odessa, Astroprint [in Ukraine].

2. Asafiev B. (1971). Musical form as a process. Moscow; Leningrad, Musyka, 379 p. [in Russian].

3. Barbier P. (2006). A history of castrats. S.-Peterburg, Izdat.Ivana Limbaha [in Russian].

4. Baltasar G.von, Bahrt K., Küng G. (1984). The theology and music. Three speeches about Mozart. Moscow, Biblelsko-Bogoslovskiy institut sv.apostola Andreja Biedermeier [in Russian]

5. Gudman F. (1995). Magic symbols. Moscow. 289 p. [in Russian].

6. Epishin A. (2006). Magic of the music baroque: italian trio-sonata. S.-Peterburg, Kompozitor [in Russian].

7. Markova E. (2012). The problem of music culturology. Odessa, Astroprint, [in Ukrainian]. Ukrainian].

8. Muravska O. (2010). The essays on histories of the foreign music culture. Issue 1. Odessa, Drukarskij dim [in

9. Nedeva-Ilijeva N. (2016). The concert repertoire for guitar and music development of the pupil. The abstract ща doctoral thesis . 05.08.02 - Misicology and music art. Sofia [in Bulgarian].

10. Poljanskajja T. (2016). Trio-sonata as genre phenomenon XVII-XVIII ct. Candidate's thesis, spec.17.00.03 mus.art. Odessa national music academy of the name A.V.Nezhdanova. Odessa [in Ukrainian].

11. Sonata [Bobrovskij V. (1981). Misical encyclopedia in 6 volumes. Editor-in-chief Ju.Keldysh. V. 5. Moscow, Sov.encyklopedija. P. 193-200[in Russian].

12. Hohlovkina A. (1962). West-European opera. The end XVIII - a first half XIX century. The essays. Moscow, Gos.muz.izdat [in Russian].

13.Heusler H. (1959). Das Biedermeier in der Musik. Die Musikforschung. XII Jahrgang. Basel-Kassel, Barenreiter Verlag. S.422-431 [in German]. 